\title{
Creativity in Mathematics: Malaysian Perspective
}

\author{
Mardiah Hafizah Muhammad Hafizi ${ }^{1}$, Nurzatulshima Kamarudin ${ }^{2, *}$ \\ ${ }^{1}$ Institute for Mathematical Research, Universiti Putra Malaysia, 43400 UPM Serdang, Selangor, Malaysia \\ ${ }^{2}$ Faculty of Educational Studies, Universiti Putra Malaysia, 43400 UPM Serdang, Selangor, Malaysia
}

Received November 4, 2019; Revised December 30, 2019; Accepted January 15, 2020

Copyright $\bigcirc 2020$ by authors, all rights reserved. Authors agree that this article remains permanently open access under the terms of the Creative Commons Attribution License 4.0 International License

\begin{abstract}
Becoming a world-class education system is one of Malaysia's aspirations that will allow the citizens to achieve their full potential besides contributing to country advancement. One of the goals of national education is to provide human resources for the needs and progress of the country. However, Malaysia is facing a phenomenon where despite its globalization in higher education, the percentage of unemployed graduates remains high. The requirement of creativity in problem-solving is not only highlighted as an essential ability in STEM education, but also one of the important skills in the industrial field. Graduates fail to meet the employer requirement due to lack of creative skills in problem-solving which leads to difficulties in getting a job. This paper attempts to discuss this deficiency from the creative perspective and highlight the reasons why it is important to study more on creativity among our students at all level especially in the field of mathematics. It is acknowledged in Malaysia's higher education blueprint where 'improving the quality of graduates' becomes one of its top five aspirations. Students' performance in tertiary mathematics is reflected by what and how students learn in primary and secondary mathematics prior to the admittance into the university. They should have the creativity to apply, connect and synthesize all the knowledge and information that they attained from primary, secondary and tertiary level to the work field. Lack of creativity in mathematics could be one of the contributing factors for the struggle that the students encounter when faced with these transitions. Without enough resources and relevant articles on mathematical creativity research in Malaysia, this is a problem to tackle for the improvement of the future generation. The need arises for researchers and educators to start to assess and fully realize the level of mathematical creativity among the students in order for the next step on developing creativity for the future and increasing quality citizens for the sake of country's growth and development.
\end{abstract}

Keywords Creativity, Mathematics, Mathematical Creativity, Problem Solving

\section{Introduction}

Developing Malaysia to be a focal point for education excellent is one of the Ministry of Education (MOE) plan. The important objective of the education system in Malaysia is to ensure that all Malaysian students in every level of education are prepared with the knowledge and skills that are relevant and required in order to be successful in the future. However, there are some issues in mathematics education that need to be tackled to achieve our educational objectives and one of them is problem-solving skills. Problem-solving is one of the major aspects of the mathematics curriculum is not only adopted in Malaysia but also all around the world. Unfortunately, it is reported that students are having difficulties in mathematics problem solving [1]. Teaching and learning of mathematics at school have been focused on problem-solving activity for the past few decades [2]. But surprisingly, students are still weak in problem-solving and they view mathematics as one of the tough and boring subjects to study and deal with a diversity of topics [3]. The goal of cultivating student's problem-solving skills can be achieved if the teacher considers more aspects of the teaching and learning process [4], [5]. Mathematics education is supposed to help and guide students understand mathematical concepts, processes and techniques, develop the ability to solve a wide variety of mathematics problems [6], [7] and importantly, contribute in life's decision making [8].

Conventional teaching strategies by demonstration, drills and practice using closed problems with expected solutions are not enough in preparing mathematical students for the future [9]. They will not have enough ability to apply their problem-solving skills successfully. In addition to that, concerns have been elevated over the past few decades that students enter university with insufficient mathematics knowledge in which the skills 
taught at school seem to be an insufficient basis for further study in tertiary mathematics. This is an awakening call for every policymakers, educator and other stakeholders in all levels of education to seek explanations on this situation. Mathematics is well known as the heart of science and mathematical creativity can help students to make sense of what is happening around them. What and how students learn in primary and secondary mathematics somehow will determine their performance in tertiary mathematics.

During school, students think that following rules is the best way to learn. So, in tertiary mathematics, they are eager to pass the examination by applying the same way of learning that they adopt from school. It became troublesome as the problems they face in tertiary mathematics involve more complex procedures and by following the traditional techniques of memorization and following rules will not be sufficient and effective anymore thus lead to failure [10]. They should have the creativity to apply, connect and synthesize all the knowledge and information that they attained from primary, secondary and tertiary level to the work field. Lack of creativity in mathematics could be one of the contributing factors for the struggle that the students encounter when faced with these transitions. It is clearly stated in the Malaysia Education Blueprint whereby every student should major a variety of cognitive skills and creativity is one of it. Therefore, creativity is one of the well-discussed topics in the world of education including Malaysia and the study related to it needs to be encouraged. Thus, the purpose of this paper is to highlight the reasons why it is important to study more on creativity in mathematics among our students at all levels of education.

\section{The needs to study Mathematical Creativity}

Nowadays, fostering creativity in education is an important goal at all levels around the world, and not only attributed to art and literature, but also in science [11]. Creativity is essential for the survival of people in a country especially in the era of globalization where change, challenge and competition are continuous. In the context of Malaysia as a nation that always ensures that infrastructure and technological developments are achieved by its citizens, the need for creativity is inevitable due to changes in government policy which concern more on the industrial sector. Mathematics is known as a primary part of human life, thus mathematics education should be considered as one of the opportunities for creativity to take part [12].

According to Sriraman [13], mathematical creativity is the degree to which a person can generate numerous solutions to mathematical problems; utilized for mathematical creative problem-solving. Mathematics is important in all fields of studies thus learning mathematics is necessary especially in courses like engineering, physics and chemistry. Also, subjects like economics, biology, psychology and sociology are increasingly requiring mathematical skills as well. Creativity is necessary elements in learning [14], teaching [9], [15], [16] and assessing mathematics, but we often overlooked it.

Mathematical creativity is important as it requires the ability of a person to discover a new relationship between techniques and area of application and also able to make associations between a possible unrelated idea [17]. It is necessary to encourage and develop a deeper understanding of the particular attributes of the relationship between creativity and mathematics [18]. In Malaysia, the Ministry of Education has done various improvements in the field of the curriculum so that education can change in parallel with changes that occur in the community whether within or outside the country. However, there are still remaining challenges that need to be confronted at every level of education.

\subsection{Primary and Secondary Mathematics}

Mathematics is a very important subject where it is taught at all academic institutions in the world such as kindergartens, primary and secondary schools, colleges and universities. Mathematics curriculum in our school has undergone various reforms in order to achieve the goal towards the formation of industrialized countries. The question is, are we really going towards it? Is mathematics curriculum in our school implemented effectively in order to achieve the goals? Hence, one of the methods used by Ministry of Education in measuring the effectiveness of education in Malaysia is by participating in an international level assessment like TIMSS and PISA which in turn can improve our education system to compete and stand together with other developed countries. However, there is an alarming concern of Malaysia student's performances in the international level assessment, especially in mathematics.

Malaysia's performance in TIMSS was seen to be inconsistent since its involvement in 1999. Between TIMSS 1999 and 2011, our mathematics and science scores dropped more than any other country. We also scored below the international averages in maths and science in TIMSS 2011. However, in TIMSS 2015, Malaysia showed improvement over previous participation in 2011 but it was still unsatisfactory. The results from TIMSS 2007 until TIMSS 2015 indicated that our students are weak in terms of reasoning skills. This situation shows that students are having difficulty to apply existing knowledge to non-routine and more complex problems [19]. This is among the reason ministry decided to put one of the main targets for education quality in the Malaysia Education Blueprint 2013-2025 is to become the top third of countries in an international assessment 
like TIMSS and PISA. More initiatives should be taken for Malaysia to be one of the top countries in the international standard performance study and therefore produce high-quality students.

On the other hand, Malaysia's performance in the Programme for International Student Assessment (PISA) also did not show much improvement. A few years ago Malaysia was ranked 52nd out of 65 in mathematics and 39 out of 44 in problem-solving [20]. Malaysian students scored 421 in Mathematics and 422 in problem-solving with the OECD average being 511 and 500 respectively. Format of PISA questions that require students to make interpretations, reflections and real-life assessments have been identified as one of the factors for the unsatisfactory performance shown by Malaysian students [21]. Mathematical problems with long sentences are problematic and often left untouched by students. They feel overwhelmed to understand the question so much that they do not want to answer that question.

In mathematics classrooms, students seem to be not really interested when confronted with new problems that they never encountered before and they usually will wait for teachers' instruction to solve any problems [22]. Students are lacking in self-confidence and afraid when dealing with problem-solving. This negative attitude often becomes a barrier for students to achieve success in mathematics. Students are expected to develop new knowledge and skills through problem-solving and apply various mathematical problem-solving strategies in a different context. They are taught what the system says they need to know rather than what is relevant and of concern to them.

Our current education emphasizes more on theoretical knowledge and intellectual growth rather than creative development among students which makes students unable to perform well in their studies as well in careers. Concern has been expressed that all levels of mathematics students have good skills in completing a practical task without conceptual understanding [23] which leads to a struggle in problem-solving. Mathematics is not only about being logical and knowing how to reason, it is also about being creative, open and communicative. Traditionally, when it comes to learning mathematics, teachers often ask students to copy something from their textbook, solve the problems and repeat the process again and again. They just follow the steps given by the teacher to solve the problems and apply to another problem without understanding the real meaning behind the process. In schools, textbooks are used as the main instructional tool. The role of the textbook should not be put aside because it acts as a guideline for the curriculum standard, but depending only on a textbook is not enough for the learning to take place. The disadvantage comes when there is no other mode of teaching or learning than textbook where students are forced to cover a lot of content, but with very little context. When there is very little context, learning becomes shallow, uninteresting and only covers the surface of the topic.

It is undeniable that mathematical creativity requires proficiency with a deep understanding of mathematical concepts and procedures. Although the language of mathematics is based on rules that must be learned, it is important for motivation that students move beyond rules to be able to express things in the language of mathematics [24]. So, being creative in mathematics requires a person to master the concepts and algorithms so that they can be applied in every situation. This component of mathematical creativity is conveyed effectively at school, but unfortunately, there is something missing in between in which makes them not being able to be creative when it comes to solving unfamiliar and complex problems. Relying on the only memorization of facts and procedures will lead to frustration as this type of mathematical problem not only requires a good understanding and procedural competency but also creativity to systematically implement the solutions to the problem. When students solve a problem successfully, their reasoning and perspective of the knowledge will be altered and modified accordingly based on the problem [4] thus, it is important for them to encounter many types of problem in mathematics that is not based on the memorization of facts and procedures only.

In the Malaysian classroom, we are having a culture where students need to listen only to the teacher and the chances for them to voice up their opinion are still limited. All students should be encouraged to participate in classroom activities and be given the opportunity to express their way of thinking without worrying about the result. As Nadjafikhah \& Yaftan [25] said, one of the most significant responsibilities of mathematics educators is to identify the development of mathematical creativity. Students should be provided with an understanding of the relevancy and connections of their current knowledge as a foundation for their future, whether pursuing the study and have a job related to mathematics.

Students' affection for mathematics seems to be decreased when they encounter more complex mathematics as they grow older [26]. Their non-participation in mathematics may be due to the fact that they cannot understand and it is easier for them to act weary or uninterested than to admit that they cannot figure out the topics or problems. Teachers need to stay positive and creative with their method of teaching and assessing students so that they won't feel demotivated as they start to struggle in confronting more complex mathematics. These students are at a growing and maturing stage of their lives where they begin to practice more decision-making skills. This stage also will determine what they will choose to study in the future. The target in mathematics education is not only in developing mathematical knowledge and skills but to make mathematics as one of the preferable subjects chosen by students so that more production of mathematicians in the future. 


\subsection{Tertiary Mathematics}

In 2017, the latest statistics provided by Ministry of Higher Education showed the number of students who pursue their tertiary education in Bachelor of Mathematics is the least compared to other fields like Science, Technology and Engineering where there are only 1258 mathematics graduates out of total 39356 graduates in STEM [27]. From these statistics, it can be explained that students showed less interest to pursue in mathematics field due to their mentality that mathematics is a tough and boring subject to study and deal with a diversity of topics [3]. On top of the lack of students pursuing an education in the mathematics field, more problems arise with students struggling to cope and sustain in this field. When it comes to tertiary mathematics, concerns have been elevated over the past few decades that students enter the university with insufficient mathematics knowledge [28] in which the skills taught at school seems to be an insufficient basis for further study in tertiary mathematics [29]. This circumstance does not only happen to mathematics students but also reported in previous studies where engineering students' claimed that mathematics is one of the difficult course to study [30].

Why is this happening? We are aware that students who enrolled in mathematics and engineering fields at universities were those with excellent achievement in secondary mathematics. The mathematical background of students entering the university, perhaps, is one of the key problems faced by educators. A study of the secondary-tertiary mathematics interface found that students' experiences during school determine the study approaches at the undergraduate level [31]. At school, students were mostly taught to produce the correct result and standard assessment structure emphasizes only on learning through routine and memorization and getting good grades in exams and does not truly measure students' creativity in mathematics, and understanding of the subject matter. The approaches and techniques used in teaching and assessing students only encourage students to receive only what they have been taught and restricted them to think outside the domain [32].

Traditionally, the standard assessment used in identifying students' ability in mathematical problem solving often value accuracy and speed [9], [33]. Focusing only on the standard test scores is not enough to determine academic success [34] and does not measure or discover creativity. The concentration is more on drilling to pass school examination, therefore, resulted in a lack of ability to use their mathematical knowledge in the new contexts they are receiving at university [28]. This explained the situation when they enter university, they will struggle as they have greater responsibility and task on the knowledge that has been taught. Students showed lack of solving mathematical problem skills that involve mathematical creativity and mathematical higher-order thinking skills, which couldn't be easily developed based on rule and memorization of facts and algorithms [35].
In addition to that, according to the Malaysian Qualification Framework (MQF), the main role of higher education is to supply first-class quality graduates with high and talented workforce skills who can contribute to our nation's development in all sectors [36]. The Malaysian Qualifications Framework (MQF) is implemented by Malaysia Qualification Agency (MQA) who is responsible for observing and supervising the quality assurance conducts and authorization of Malaysia's higher education. One of the skills required is the ability to solve a variety of complex problems by applying a range of necessary techniques and procedures. To achieve this skill, graduates need to have creativity to apply, connect and synthesize all the knowledge and information required in the field of study or work.

The Ministry of Higher Education's MHEB 2015-2025 blueprint outlines 10 shifts that will enhance higher education excellence. The first design is to produce holistic, entrepreneurial and balanced graduates who can better navigate and shape their futures independently. However, recently it was reported that a total of 54103 out of 238187 Malaysian graduates were jobless for six months after they finished their studies in university [37]. Although higher education keeps globalizing its reach, the percentage of Malaysia's unemployed graduates also shows rising increments. This trend is recognized by the latest Malaysia higher education blueprint where 'improving the quality of graduates' is marked as one of five aspirations, and predominately considered due to an imbalanced production of graduates over the years. For example, HRM Asia (2012) reported that there are nearly 150,000 graduates from Malaysian universities. However most failed to find employment [31]. The latest report provided by Bank Negara Malaysia showed that between 2010 and 2017, the number of tertiary graduates entering the workforce surpassed the number of jobs created for them [38].

This phenomenon forces graduates to compete for jobs and with insufficient skills. It is hard for them to be well-matched in the labour market. This is an awakening call for every policymakers, educator and other stakeholders to see the reasons and problems behind the unemployment among graduates. Creativity could be one of the contributing factors to this situation. They are struggling in applying and connecting what they have learned in terms of their mathematical understanding, learning approaches and conceptions of mathematics to the undergraduate setting. From an industrial perspective, creativity is one of the necessary skills that graduates must possess for them to be employed [39]. They are not aware of employers' expectations and not prepare themselves to enter the working world [39]. Education systems should focus less on the reproduction of information and more on creativity and problem solving because how students consume and learn today are very different from past generations. Hence, educators in Malaysia need to provide the right environment, updated tools, foster innovative 
problem-solving skills and creative outlets to bring out the best in their students for the need of future workforce.

\subsection{Creativity Research in Malaysia}

There is an increasing awareness of the worth of fostering creativity in education and the benefits to individuals and societies have also been increasingly acknowledged. Yet, a few studies on creativity have been conducted in Malaysia. Table 1 below illustrated the details on some of the studies related to creativity that have been conducted in the Malaysian context.

Several factors have been identified as being related to creativity such as gender [40], [41], ethnicity [41], technology [32], [42], [43], environment [44]-[48], academic achievement [40], and cognitive [49]-[53].

A study on creativity and innovation based on gender and ethnicity was employed by Siti Rahayah et al. [41] using Malaysian Creativity and Innovation Instrument (MyCrIn) to measure the levels of creativity and innovation among students at a higher learning institution (HLI). The study found out that male students demonstrated a higher ability of higher-order thinking skills as compared to female and there is no difference in the level of creativity among ethnicity. There is also a few researchers study creativity among undergraduate students [40], [47], [53]-[55]. For instance, Keh, Zaleha, \& Yudariah [47] conducted exploratory research involving 96 engineering undergraduates. The assessment of creativity in this research was based on the comparison in the creativity level among the groups where they worked collaboratively in the process of problem-solving. It was found that working in a group provides a platform for students to express their creativity to produce several methods of solving a real-world problem.

In another study, Huda, Wan Nurul Izza, \& Tareq [55] carried out research to find out that the barriers to creativity among 459 engineering undergraduates in several public universities in Malaysia. According to them, barriers to creativity among engineering undergraduates in Malaysia include barriers related to self-concept, barriers related to compliance need, barriers related to abstract ability, barriers related to systematic analysis, barriers related to task achievement and barriers related to environmental circumstances. The findings indicated that undergraduates have the most difficult barriers related to task achievement followed by barriers related to self-concept and barriers related to environmental circumstances [55]. Related research on barriers to creativity was conducted by Niloufar et al. [48] where they believed that in developing creativity, the focus should not be only on the elements that promote creativity, but also the barriers that might reduce creativity development. They investigated creativity related to the familial factor where they suggested that one way to promote positive thinking among Malaysians is to develop a strategy to build beneficial programs designed to enhance creativity within members of the family [48].

Some researchers studied creativity related to educators. Factors involving educators can determine whether creative teaching and learning will take place or not [44]-[46]. Afida et al. [42] stated that a study on creative educators can describe ways to enhance creativity and enrich teaching practices. Palaniappan [44] designed an instrument called Creative Teaching Inventory (CTI) to assess creative teaching among randomly 78 teachers from secondary schools in the Klang Valley in Selangor. This instrument was designed based on a creative teaching model that is currently being used in workshops involving teachers and trainers in Malaysia. In a different study, Afshari et al. [43] attempted to study the relationship between leadership behavior of lectures with students' creativity. They conducted exploratory research involving 520 Master and Ph.D. students in the faculties of education at three selected research universities in Malaysia. The findings of the study concluded that leadership behaviours' of lecturers have powerful influences on students' creativity.

On the other hand, Noraini \& Norjoharuddeen [42] discussed the essence of mathematical creativity from the perspective of technology usage whereby to possess the mathematical knowledge to produce, use and manipulate new technologies in Malaysia, improvement in mathematical achievement in Malaysian students needed to be cultivated to achieve a mathematically competent and creative Malaysian workforce. Related research incorporated technology for creativity enhancement was conducted by Fauziah [43] involving physics undergraduates. She proposed that PBL online can increase students' creative thinking based on the result where students that engaged in PBL online perform better in term of creativity compared to the group with the traditional method of learning [43].

Although there is a rapidly rising interest in creativity globally, the amount of valid and reliable measures to assess mathematical creativity is still not enough [56], especially in the Malaysian context. Several studies adopted and developed variety of instruments to access creativity such as Yanpiaw Creative-Critical Thinking Styles Test or YCREATIVE-CRITICALS (creative and critical thinking styles) [52], [51], MyCrIn [41], inventory of barriers to creative thought and innovative action [55], Nicolas Holt Creativity Test (NHCT) [40], The Torrance Test of Creative Thinking (TTCT) [43], [49], [54][51], other written test involving problem solving [47], [53]. However, little attention has been emphasized on the creativity tests that focus on the way students solve the problems creatively. Some researchers have focused on the assessment of creativity yet there is hardly any substantive research that emphasizes mathematical creativity especially in the way they work with mathematics problems. Thus, emphasis needs to be given to the study on creativity for the improvement and better quality of mathematics education. 
Table 1. Some of the research related to creativity conducted in Malaysia

\begin{tabular}{|c|c|c|c|}
\hline Author & Purpose & Sample & Result \\
\hline Keh et al. (2017) & $\begin{array}{l}\text { Study creativity among the } \\
\text { geomatical engineering students }\end{array}$ & $\begin{array}{l}96 \text { geomatical } \\
\text { engineering students ( } 24 \\
\text { groups of } 4 \text { students) }\end{array}$ & $\begin{array}{l}\text { Students were able to work in a group and } \\
\text { use their creativity to come out with many } \\
\text { methods of solving the real-world problem }\end{array}$ \\
\hline Fuzirah et al. (2017) & $\begin{array}{l}\text { Analyzes students' descriptions of } \\
\text { creativity }\end{array}$ & $\begin{array}{l}41 \text { undergraduates from } \\
\text { School of Media and } \\
\text { Communication Studies, } \\
\text { UKM }\end{array}$ & Students are more critical than creative \\
\hline $\begin{array}{l}\text { Niloufar et al. } \\
\text { (2014) }\end{array}$ & $\begin{array}{c}\text { Investigate the impact of barriers of } \\
\text { enhancing creativity developed by } \\
\text { parents upon children's creativity } \\
\text { level }\end{array}$ & $\begin{array}{c}\text { Parent with children (5-7 } \\
\text { years old) }\end{array}$ & $\begin{array}{c}\text { Children whose parents erect creativity } \\
\text { barriers have a lower level of creativity } \\
\text { compared to children whose parents behave } \\
\text { otherwise }\end{array}$ \\
\hline $\begin{array}{l}\text { Ali Salim \& Hairul } \\
\text { Nizam (2014) }\end{array}$ & $\begin{array}{l}\text { Study the effects of thinking on } \\
\text { thinking and control group }\end{array}$ & 68 standard 5 students & $\begin{array}{l}\text { Significant differences in post-test scores } \\
\text { with respect to experimental group } \\
\text { compared to control groups. }\end{array}$ \\
\hline $\begin{array}{l}\text { Saeideh \& Nooreen } \\
\text { (2013) }\end{array}$ & $\begin{array}{l}\text { Study the relationship between } \\
\text { creativity and academic achievement }\end{array}$ & $\begin{array}{l}100 \text { undergraduate in } \\
\text { TESL }\end{array}$ & $\begin{array}{l}\text { Female students had higher creativity and } \\
\text { academic achievement compared to male. }\end{array}$ \\
\hline Huda (2013) & $\begin{array}{l}\text { Investigate the barriers to creativity } \\
\text { particularly the creative thought and } \\
\text { innovative action }\end{array}$ & $\begin{array}{c}459 \text { respondents from } \\
\text { several universities UM, } \\
\text { USM, IIUM, UTM, and } \\
\text { UKM }\end{array}$ & $\begin{array}{l}\text { Barriers related to task achievement are the } \\
\text { most critical barrier to creativity. }\end{array}$ \\
\hline Fauziah (2013) & $\begin{array}{l}\text { Study the effectiveness of PBL } \\
\text { Online on physics students' } \\
\text { creativity and critical thinking }\end{array}$ & $\begin{array}{l}61 \text { physics students from } \\
\text { the School of Science } \\
\text { and Technology (SST) } \\
\text { of UMS }\end{array}$ & $\begin{array}{l}\text { PBL online effectively improves both of } \\
\text { physics students' creativity and critical } \\
\text { thinking }\end{array}$ \\
\hline Afida et al. (2013) & $\begin{array}{c}\text { Reviews research on creative } \\
\text { lecturers }\end{array}$ & - & $\begin{array}{c}\text { Creative lecturers play a role in students' } \\
\text { creativity }\end{array}$ \\
\hline Afida et al. (2012) & $\begin{array}{l}\text { Assess the creativity level of } \\
\text { engineering undergraduates }\end{array}$ & $\begin{array}{l}18 \text { undergraduates from } \\
\text { Faculty of Engineering, } \\
\text { UKM }\end{array}$ & $\begin{array}{c}\text { More than half students have above average } \\
\text { creativity scores }\end{array}$ \\
\hline Afida et al. (2011) & $\begin{array}{c}\text { Investigate how construct-based } \\
\text { creativity models reflect creative } \\
\text { behaviour through an } \\
\text { experiential-based learning } \\
\text { environment }\end{array}$ & $\begin{array}{l}\text { Undergraduate students } \\
\text { from UKM who took } \\
\text { part in the Malaysian } \\
\text { ROBOCON } 2010\end{array}$ & $\begin{array}{c}\text { Experiential learning activities nurtured and } \\
\text { enhanced students' creativity in } \\
\text { problem-solving }\end{array}$ \\
\hline $\begin{array}{l}\text { Siti Rahayah et al. } \\
\text { (2011) }\end{array}$ & $\begin{array}{l}\text { Profile students of HLI according to } \\
\text { levels of creativity and innovation } \\
\text { based on gender and ethnicity }\end{array}$ & 300 undergraduates & $\begin{array}{l}\text { Male students exhibited a higher ability of } \\
\text { higher-order thinking skills. No difference in } \\
\text { the level of creativity in term of ethnicity. }\end{array}$ \\
\hline Chua (2011) & $\begin{array}{c}\text { Establishing a Brain Styles Test: The } \\
\text { YBRAINS Test }\end{array}$ & $\begin{array}{l}\text { Secondary school } \\
\text { students }\end{array}$ & $\begin{array}{l}\text { YBRAINS scores were able to } \\
\text { represent the brain styles }\end{array}$ \\
\hline Chua (2010) & $\begin{array}{c}\text { Measure creative and critical } \\
\text { thinking style of the students } \\
\text { simultaneously using } \\
\text { YCREATIVE-CRITICALS }\end{array}$ & Age sixteen and above & $\begin{array}{l}\text { YCREATIVE-CRITICALS scores were able } \\
\text { to represent the styles of creative thinking } \\
\text { and critical thinking }\end{array}$ \\
\hline $\begin{array}{l}\text { Noraini \& } \\
\text { Norjoharuddeen } \\
\quad(2010)\end{array}$ & $\begin{array}{l}\text { Discuss the essence of mathematical } \\
\text { creativity and the impact of } \\
\text { technology on creativity in } \\
\text { mathematics. }\end{array}$ & - & $\begin{array}{l}\text { Technology can empower and provide } \\
\text { students all the tools necessary for } \\
\text { promoting creativity. }\end{array}$ \\
\hline Palaniappan (1998) & $\begin{array}{c}\text { Study figural creativity and } \\
\text { cognitive preferences among } \\
\text { undergraduates }\end{array}$ & $\begin{array}{l}165 \text { undergraduates from } \\
\text { education department, } \\
\text { UM }\end{array}$ & $\begin{array}{l}\text { Figural creativity and its components were } \\
\text { not significantly related to the students' } \\
\text { modes of cognitive preferences or their } \\
\text { factor scores }\end{array}$ \\
\hline
\end{tabular}

Considering creativity in mathematics education can provide guidance and help students to make sense of the surrounding by reasoning, thinking logically and connecting the ideas to discover the meaning of real-world [32]. Hence, it is very important to study mathematical creativity among students in Malaysia. Without enough resources and relevant articles on mathematical creativity research done in Malaysia, this might be a problem for us to tackle this problem from the core. Thus, the needs become apparent for researchers and educators to start to assess and fully realize the level of mathematical creativity among our students so that we can take the next step on how to make them more creative in the future.

\section{Conclusions}

Research in the field of creativity is essential for future growth and development of this modern world, therefore, 
it needs to be studied thoroughly [18]. Creativity in mathematical problem solving for all levels of educations should not be ignored during mathematics curriculum development. The efforts for creativity ought to be recognized since creativity encourages and enriches problem-solving. Education systems should focus less on the reproduction of information and more on creativity in problem-solving because students with a package of creativity, strong conceptual knowledge and good procedural competency would have a better opportunity to succeed in this global challenging era. How students consume and learn today are very different from past generations and what is needed by today's students might look very different in the future. Hence, this paper is hoped to give a sparks for researchers, educators and policymakers in Malaysia to look and dig more on creativity in mathematics so that we are able to provide the right environment, updated tools and creative outlets to bring out the best in the students and foster innovative problem-solving skills the future workforce need.

\section{REFERENCES}

[1] T. Tambychik and T. S. M. Meerah, "Students' difficulties in mathematics problem-solving: What do they say?," Procedia - Soc. Behav. Sci., vol. 8, no. 5, pp. 142-151, 2010.

[2] A. H. Schoenfeld, "Looking toward the 21st Century: Challenges of Educational Theory and Practice," Educ. Res., vol. 28, no. 7, p. 4, 1999.

[3] S. Bishara, "Creativity in unique problem-solving in mathematics and its influence on motivation for learning," Cogent Educ., vol. 3, no. 1, pp. 1-14, 2016.

[4] F. M. Singer and C. Voica, "A problem-solving conceptual framework and its implications in designing problem-posing tasks," Educ. Stud. Math., vol. 83, no. 1, pp. 9-26, 2013.

[5] F. K. Lester Jr., "Thoughts About Research On Mathematical Problem-Solving Instruction," Math. Enthus., vol. 10, no. 10, pp. 1551-34401, 2013.

[6] W. C. Mkomange, B. Ilembo, and M. A. Ajagbe, "The roles and importance of technology in mathematics teaching and learning-a literature review," Interdiciplinary J. Contemp. Res. Bus., vol. 3, no. 11, pp. 476-486, 2012.

[7] J. W. Wilson, M. L. Fernandez, and N. Hadaway, "Mathematical Problem Solving," Synthesis (Stuttg)., no. 33, pp. 1-18, 2007.

[8] M. E. Little, "Teaching Mathematics: Issues and Solutions," Teach. Except. Child. Plus, vol. 6, no. 1, pp. 1-16, 2009.

[9] E. L. Mann, "Creativity: The Essence of Mathematics," J. Educ. Gift., vol. 30, no. 2, pp. 236-260, 2006.

[10] Y. Yusof and D. Tall, "Changing Attitudes to University Mathematics through Problem Solving," Proc. Eighteenth Conf. Psychol. Math. Educ., vol. 37, pp. 67-82, 1999.

[11] M. Nadjafikhah, N. Yaftian, and S. Bakhshalizadeh,
"Mathematical creativity: Some definitions and characteristics," Procedia - Soc. Behav. Sci., vol. 31, no. 2011, pp. 285-291, 2012.

[12] V. Švecová, L. Rumanová, and G. Pavlovičová, "Support of Pupil's Creative Thinking in Mathematical Education," Procedia - Soc. Behav. Sci., vol. 116, pp. 1715-1719, 2014.

[13] B. Sriraman, "The characteristics of mathematical creativity," ZDM - Int. J. Math. Educ., vol. 14, no. 1, pp. 19-34, 2004.

[14] M. S. Badger, C. J. Sangwin, T. O. Hawkes, R. P. Burn, J. Mason, and S. Pope, Teaching Problem-solving in Undergraduate Mathematics. 2012.

[15] G. A. Goldin, "Mathematical creativity and giftedness: perspectives in response," ZDM - Math. Educ., vol. 49, no. 1, pp. 147-157, 2017.

[16] Y. Sharma, "The effects of strategy and mathematics anxiety on mathematical creativity of school students," Int. Electron. J. Math. Educ., vol. 9, no. 1-2, pp. 25-37, 2014.

[17] D. W. Haylock, "A framework for assessing mathematical creativity in school chilren," Educ. Stud. Math., vol. 18, no. 1, pp. 59-74, 1987.

[18] J. S. Kozlowski and S. Si, "Mathematical creativity: A vehicle to foster equity," Think. Ski. Creat., vol. 33, no. June, 2019.

[19] A. H. Abdullah, "Pentaksiran Timss: Di Manakah Kedudukan Pelajar Malaysia?," Dewan Masyarakat, no. April, pp. 21-24, 2018.

[20] OECD, "PISA 2012 Results in Focus: What 15-year-olds know and what they can do with what they know," 2014.

[21] A. H. Abdullah, J. Surif, and N. H. Ibrahim, "PISA 2012: Di mana kedudukan Malaysia untuk subjek Matematik?," Pros. Semin. Antarabangsa Kelestarian Insa., no. 9-10 April 2016, pp. 1-17, 2014.

[22] F. K. Lester Jr. and S. T. Mau, "Teaching Mathematics via Problem Solving: a Course for Prospective Elementary Teachers [I]," Learn. Math., vol. 13, pp. 8-11, 1993.

[23] T. A. Jensen, "A Study of The Relationship Between Introductory Calculus Students' Understanding of Function and Their Understanding of Limit by Taylor Austin Jensen A dissertation submitted in partial fulfillment of the requirements for the degree of Doctor of Philoso," 2009.

[24] A. H. Schoenfeld, "Learning to think mathematically: problem solving, metacognition and sense-making in mathematics," Handb. Res. Math. Teach. Learn., pp. 334-370, 1992.

[25] M. Nadjafikhah and N. Yaftian, "The Frontage of Creativity and Mathematical Creativity," Procedia - Soc. Behav. Sci., vol. 90, no. InCULT 2012, pp. 344-350, 2013.

[26] I. V. S. Mullis, M. O. Martin, and T. Loveless, "20 Years of TIMSS International Trends in Mathematics and Science Achievement, Curriculum, and Instruction,” 2016.

[27] MOHE, Ministry of Higher Education, "Statistik Pendidikan Tinggi 2017: Universiti Awam," Putrajaya, 2017. 
[28] ACME, "Mathematical Needs: Mathematics in the workplace and in Higher Education," London, 2011.

[29] E. Darlington and J. Bowyer, "Undergraduate Mathematics students' views of their pre-university mathematical preparation," Res. Matters A Cambridge Assess. Publ., pp. $2-11,2017$.

[30] H. Kashefi, Z. Ismail, and Y. Mohammad, "Supporting Engineering Students' Thinking and Creative Problem Solving through Blended Learning," vol. 56, no. Ictlhe, pp. $117-125,2012$

[31] A. Kajander and M. Lovric, "Transition from secondary to tertiary mathematics: McMaster University experience,' Int. J. Math. Educ. Sci. Technol., vol. 36, no. 2-3, pp. 149-160, 2005.

[32] N. Idris, "Creativity in The Teaching and Learning of Mathemtics: Issues and Prospects," Masal. Pendidikan, Univ. Malaya, pp. 103-113, 2006.

[33] H.-W. Kim, S. Cho, and D. Ahn, "Development of Mathematical Creative Problem Solving Ability Test for Identification of the Gifted in Math," Gift. Educ. Int., vol. 18 , no. 2 , pp. $164-174,2004$.

[34] UNESCO, "Education for All 2015 National Review Report: Malaysia,” World Educ. Forum, pp. 1-128, 2015.

[35] Ministry of Education, "Malaysia Education Blueprint 2015-2025," Minist. Educ. Malaysia, vol. 2025, 2015.

[36] MOHE, Ministry of Higher Education "Malaysian Qualifications Framework ( MQF )," 2013.

[37] MOHE, Ministry of Higher Education, "Bab 6:Graduan 2016 (Warganegara) Yang Belum Bekerja Sempena Musim Konvokesyen Masing-Masing,” 2016.

[38] B. A. Murugasu, M. I. Hakim, and Y. S. Yau, "Are Malaysian Workers Paid Fairly?: An Assessment of Productivity and Equity," 2018.

[39] M. C. H. Ang, "Graduate Employability Awareness: A Gendered Perspective," Procedia - Soc. Behav. Sci., vol. 211, no. September, pp. 192-198, 2015.

[40] B. Saeideh and N. Nooreen, "Investigating the relationship between creativity and academic achievement of Malaysian undergraduates," J. Teknol. (Sciences Eng., vol. 65 , no. 2, pp. 101-107, 2013.

[41] A. Siti Rahayah, D. Faiz, A. Roseni, R. Nur Aidah, and B. Ayesha, "Profile of Creativity and Innovation Among Higher Learning Institution Students in Malaysia Department of Public Health, University Kebangsaan Medical Centre," World Appl. Sci. J. 15 (Innovation Pedagog. Lifelong Learn., vol. 15, pp. 36-41, 2011.

[42] N. Idris and N. M. Nor, "Mathematical creativity: Usage of technology," Procedia - Soc. Behav. Sci., vol. 2, no. 2, pp. 1963-1967, 2010.
[43] S. Fauziah, "The Effectiveness of PBL Online on Physics Students' Creativity and Critical Thinking: A Case Study at Universiti Malaysia Sabah," Int. J. Educ. Res., vol. 1, no. 3, pp. 1-18, 2013.

[44] A. Afida, H. Aini, and A. M. Rosadah, "A Review of Research on Creative Teachers in Higher Education," Int. Educ. Stud., vol. 6, no. 6, pp. 61-65, 2013.

[45] M. Afshari, S. Siraj, M. F. a Ghani, A. Zabidi, and A. Razak, "Enhancing Students' Creativity at Research Universities in Malaysia," Arch. Des Sci., vol. 65, no. 6, pp. 166-172, 2012.

[46] A. K. Palaniappan, "Creative teaching and its assessment," in 12th UNESCO-APEID International Conference, 2009, no. January 2009.

[47] L. K. Keh, I. Zaleha, and M. Y. Yudariah, "Creativity among Geomatical Engineering Students," Int. Educ. Stud., vol. 10, no. 4, p. 43, 2017.

[48] N. T. Ahmadi, S. Mustaffa, and A. Ahmadi, "The Barriers of Enhancing Creativity Developed by Parents in Developing Countries," Procedia - Soc. Behav. Sci., vol. 114, pp. 257-261, 2014.

[49] A. K. Palaniappan, "Figural creativity and cognitive preference among malaysian undergraduate students," J. Psychol. Interdiscip. Appl., vol. 132, no. 4, pp. 381-388, 1998.

[50] R. A. Ali Salim and I. Hairul Nizam, "The Effects of Integrating Creative and Critical Thinking on Schools Students' Thinking,” Int. J. Soc. Sci. Humanit., vol. 4, no. 6, pp. 518-525, 2014.

[51] Y. P. Chua, "Establishing a Brain Styles Test: The YBRAINS Test," Procedia - Soc. Behav. Sci., vol. 15, pp. 4019-4027, 2011.

[52] Y. P. Chua, "Building a test to assess creative and critical thinking simultaneously," Procedia - Soc. Behav. Sci., vol. 2, no. 2, pp. 551-559, 2010.

[53] H. Fuzirah, A. Jamaluddin, and A. Abdul Latiff, "Transformation In Malaysian Higher Education: Students 'Understanding Of Creativity In Social Sciences," J. Soc. Sci. Humanit., vol. 12, no. 3, 2017.

[54] A. Ayob, A. Hussain, M. M. Mustaffa, and R. A. Majid, "Assessment of Creativity in Electrical Engineering," Procedia - Soc. Behav. Sci., vol. 60, no. 1974, pp. 463-467, 2012.

[55] M. H. H. Huda, W. H. Wan Nurul Izza, and M. Z. Tareq, "Barriers to Creativity among Students of Selected Universities in Malaysia," Int. J. Appl. Sci. Technol., vol. 3, no. 6, pp. 51-60, 2013.

[56] S. Akgul and N. G. Kahveci, "A Study on the Development of a Mathematics Creativity Scale," Eurasian J. Educ. Res., no. 62 , pp. $57-76,2016$ 